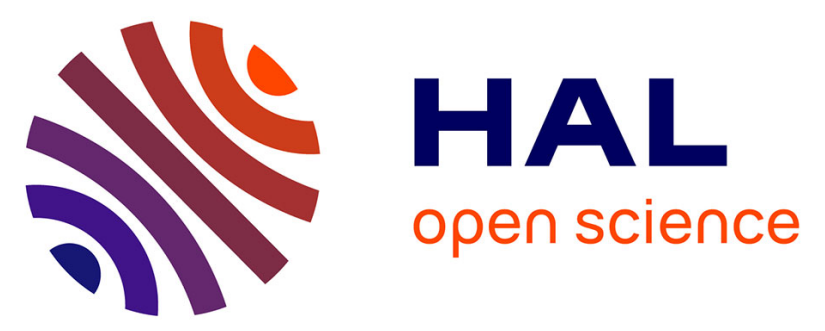

\title{
Disease-Induced Alterations in Brain Drug Transporters in Animal Models of Alzheimer's Disease
}

Kati-Sisko Vellonen, Jouni Ihalainen, Marie-Christine Boucau, Fabien

Gosselet, Théo Picardat, Mikko Gynther, Katja Kanninen, Anthony White, Tarja Malm, Jari Koistinaho, et al.

\section{To cite this version:}

Kati-Sisko Vellonen, Jouni Ihalainen, Marie-Christine Boucau, Fabien Gosselet, Théo Picardat, et al.. Disease-Induced Alterations in Brain Drug Transporters in Animal Models of Alzheimer's Disease. Pharmaceutical Research, 2017, 34 (12), pp.2652-2662. 10.1007/s11095-017-2263-7 . hal-02506588

\section{HAL Id: hal-02506588 \\ https://hal-univ-artois.archives-ouvertes.fr/hal-02506588}

Submitted on 23 Jul 2021

HAL is a multi-disciplinary open access archive for the deposit and dissemination of scientific research documents, whether they are published or not. The documents may come from teaching and research institutions in France or abroad, or from public or private research centers.
L'archive ouverte pluridisciplinaire HAL, est destinée au dépôt et à la diffusion de documents scientifiques de niveau recherche, publiés ou non, émanant des établissements d'enseignement et de recherche français ou étrangers, des laboratoires publics ou privés.

\section{(c)(1)}

Distributed under a Creative Commons Attribution| 4.0 International License 


\section{Disease-Induced Alterations in Brain Drug Transporters in Animal Models of Alzheimer's Disease}

\section{Theme: Drug Discovery, Development and Delivery in Alzheimer's Disease Guest Editor: Davide Brambilla}

Kati-Sisko Vellonen ' (D) J Jouni Ihalainen ' - Marie-Christine Boucau ${ }^{2} \cdot$ Fabien Gosselet ${ }^{2} \cdot$ Théo Picardat ' Mikko Gynther' Katja M. Kanninen ${ }^{3} \cdot$ Anthony R. White ${ }^{4} \cdot$ Tarja Malm $^{3} \cdot$ Jari Koistinaho $^{3} \cdot$ Markus M. Forsberg ' Marika Ruponen '

Received: 20 June 2017 / Accepted: 12 September 2017 / Published online: 26 September 2017

(C) Springer Science+Business Media, LLC 2017

\begin{abstract}
Purpose Alzheimer's disease (AD) may disturb functions of the blood-brain barrier and change the disposition of drugs to the brain. This study assessed the disease-induced changes in drug transporters in the brain capillaries of transgenic AD mice.

Methods Eighteen drug transporters and four tight junctionassociated proteins were analyzed by RT-qPCR in cortex, hippocampus and cerebellum tissue samples of 12-16month-old APdE9, Tg2576 and APP/PS1 transgenic mice and their healthy age-matched controls. In addition, microvessel fractions enriched from 1-3-month-old APdE9 mice were analyzed using RT-qPCR and Western blotting. Brain transport of methotrexate in APdE9 mice was assessed by in vivo microdialysis.

Results The expression profiles of studied genes were similar in brain tissues of $\mathrm{AD}$ and control mice. Instead, in the microvessel fraction in APdE9 mice, >2-fold alterations were detected in the expressions of 11 genes but none at the protein level. In control mice strains, $>5$-fold changes between different brain regions were identified for Slc15a2, Slc22a3 and
\end{abstract}

Electronic supplementary material The online version of this article (https://doi.org/I 0. 1007/s I | 095-0 17-2263-7) contains supplementary material, which is available to authorized users.

Kati-Sisko Vellonen

Kati-Sisko.Vellonen@uef.fi

School of Pharmacy, University of Eastern Finland, P.O. Box 1627 , 702 II Kuopio, Fl, Finland

2 Laboratoire de la barrière hémato-encéphalique (LBHE), University Artois, Lens, France

3 A. I. Virtanen Institute for Molecular Sciences, University of Eastern Finland, Kuopio, Finland

4 QIMR Berghofer Medical Research Institute, Herston, QLD, Australia occludin. Methotrexate distribution into hippocampus of APdE9 mice was faster than in controls.

Conclusions The expression profile of mice carrying presenilin and amyloid precursor protein mutations is comparable to controls, but clear regional differences exist in the expression of drug transporters in brain.

KEY WORDS APdE9 - blood-brain barrier · brain disposition · brain microdialysis . CNS exposure . pharmacokinetics

$\begin{array}{ll}\text { ABBREVIATIONS } \\ \text { AD } & \text { Alzheimer's disease } \\ \text { amyloid- } \beta & \text { A } \beta \\ \text { BBB } & \text { Blood-brain barrier } \\ \text { CB } & \text { Cerebellum } \\ \text { CX } & \text { Cortex } \\ \text { HC } & \text { Hippocampus } \\ \text { wt } & \text { Wild type }\end{array}$

\section{INTRODUCTION}

Alzheimer's disease (AD) is the most common form of dementia; it is associated with accumulation of senile plaques and neurofibrillary tangles in the brain (1). The extracellular senile plaques are mainly formed by aggregating amyloid- $\beta(A \beta)$ peptides in the brain parenchyma, whereas hyperphosphorylated and misfolded tau proteins are the main constituent of the intraneuronal neurofibrillary tangles.

The distribution of drug molecules from the systemic circulation to the brain is controlled and limited by the blood-brain barrier (BBB). The BBB is formed by capillary endothelial cells and supported by the end feet of astrocytes and pericytes around brain capillaries. Dysfunction of the BBB has been 
associated with neurodegeneration, although the importance of $\mathrm{BBB}$ alterations solely attributable to $\mathrm{AD}$, without the presence of additional vascular diseases, is still unclear (2). A dysfunctional BBB may alter the access of AD drugs to their site of action; it may either increase the drug exposure to the brain, potentially causing unwanted effects, or decrease drug access and lead to an insufficient response. AD patients are generally over 65 years old, and in addition to $\mathrm{AD}$ drugs, they often have medication for several other chronic diseases. Therefore, BBB dysfunction can also either increase or decrease the brain distribution of other concomitant medications and possibly increase their adverse effects on the central nervous system.

The BBB is enriched with several transporter proteins belonging to the ATP binding cassette (ABC) and solute carrier (SLG) gene families; these are responsible for ensuring the supply of dietary components into the brain and the disposal of metabolic products from the brain, as well as preventing noxious agents accessing the brain from the circulation (3). Transporters have also a significant role in the pharmacokinetics of many drugs. For instance, L-dopa, which is used to treat Parkinson's disease, crosses the BBB via the influx carrier L-type amino acid transporter (LAT1). Furthermore, the efflux transporter Multidrug resistance protein 1 (MDR1, Pglycoprotein) is known to diminish the central access of various drug molecules. In addition, high levels of efflux transporters including Breast cancer resistance protein (BCRP, ABCG2) and Multidrug resistance-associated protein 4 (MRP4, ABCC4) are expressed by the endothelial cells in the BBB (4). Other transporters, relevant also as drug carriers, such as MRP proteins (MRP1, MRP5), monocarboxylate (MCT1), nucleoside (ENT1) and organic cation (OCT3) and anion (OAT3) transporters, organic anion transporting polypeptides (OATPs) and multidrug and toxin extrusion protein 1 (MATE1) have been localized in the endothelial cells of human and mouse brain capillaries (3-7).

The influence of $\mathrm{AD}$ on the expression and functionality of some BBB drug transporters has been studied both in postmortem AD patient samples and animal models of AD. MDR1 has been the most widely studied efflux protein in $\mathrm{AD}$ and in addition to a wide variety of drug molecules it has been shown to also transport $\mathrm{A} \beta$ (8). Downregulation of MDR 1 expression in brain capillaries in close proximity to A $\beta$ deposits of $\mathrm{AD}$ patients has been observed by several groups (9-13). In addition to expression, a positron emission tomography study investigated MDR 1 function in the $\mathrm{BBB}$ of $\mathrm{AD}$ patients with MDR1 substrate $(\mathrm{R})-\left[{ }^{1} \mathrm{C}\right]$ verapamil and found evidence of decreased efflux function (14). The findings related to the impact of $\mathrm{AD}$ on BCRP expression have revealed minor and also partly conflicting alterations $(10,12,13,15)$ and a slight upregulation of MRP4 expression at both RNA and protein levels has been detected in the hippocampus of $\mathrm{AD}$ patients (10). There are even fewer studies examining diseaseinduced changes in drug transporter expression in $\mathrm{AD}$ mouse models. With respect to Mdrl, both up- and down-regulation have been reported, whereas increase in expression levels of Bcrp have been detected $(8,16,17)$. However, there are many transporters whose expression and functionality in $\mathrm{AD}$ remain obscure i.e. no comprehensive comparative data is available.

Transgenic mouse models of $\mathrm{AD}$, which have mutations in amyloid precursor protein (APP), such as Tg2576, or in both APP and presenilin (PSEN1) genes, such as APdE9 and APP/ PS1 mouse models, can provide useful information on AD pathogenesis and disease mechanisms. APdE9 mice exhibit an increase in the parenchymal $\mathrm{A} \beta$ load, with the appearance of $\mathrm{A} \beta$ plaques starting from the age of four months; APP/PS1 mice develop $\mathrm{A} \beta$ deposits around 9 months of age, and Tg2576 mice around 10 months of age. In addition, signs of gliosis can be seen concurrently. Disease models are important tools for drug development. For example, the pharmacokinetic properties of novel $\mathrm{AD}$ drug candidates can be studied in models having similar disease-induced alterations as $\mathrm{AD}$ patients. Before these AD models can be better exploited in preclinical drug development, it would be important to acquire a more detailed characterization of the drug transporters.

This study aimed to characterize the expression of drug transporters and tight junction-associated proteins in three mouse models of AD, the APdE9, APP/PS1 and Tg2576 mice, and to investigate the regional expression differences in the brain. In order to assess the effect of $\mathrm{AD}$ pathology on drug transport into the brain in vivo, we applied a pharmacokinetic microdialysis method to measure the unbound extracellular drug levels in the hippocampus after systemic administration of methotrexate.

\section{MATERIALS AND METHODS}

\section{Animals}

All procedures were made in compliance with the European Communities Council Directive (86/609/EEG) and Principles of laboratory Animal Care, and studies were approved by the National Animal Experiment Board. The animals were kept in a controlled environment with $12 \mathrm{~h}$ light/ dark cycle and food and water freely available. Brain tissue samples were collected from male APP/PS1dE9 (APdE9) mice (C57BL/6 J strain) (18) at the age of 16 months $(n=3-$ 4), female APP/PS1 mice (C57BL/6J strain) (19) at the age of 12-15 months $(n=3-4)$ and female Tg2576 mice (C57BL/ 6JxSJL strain) (20) at the age of $12-15$ months $(n=4)$. All mice groups had age-matched wildtype (wt) controls $(\mathrm{n}=3-5)$. During sample collection, the mice were anesthetized with $250 \mathrm{mg} / \mathrm{kg}$ Avertin and perfused $3 \mathrm{~min}$ transcardially with heparinized $(2500 \mathrm{IU} / \mathrm{l})$ saline at a flow rate of $20 \mathrm{ml} / \mathrm{min}$. The cortical (CX), hippocampal (HC) and cerebellar (CB) samples were dissected and snap frozen in liquid nitrogen. 
$\mathrm{A} \beta$ accumulates mainly in $\mathrm{CX}$ and $\mathrm{HC}$, whereas $\mathrm{CB}$ remains devoid of $\mathrm{Ab}$ deposits and was therefore considered as unaffected control tissue.

\section{Mechanical Isolation of Brain Capillaries}

The microvessel enriched fraction was isolated from 5-12 weeks old female APdE9 mice as previously described by Coisne et al. (21). Briefly, ten cortices, from APdE9 or wt mice were isolated by removing cerebellum and brain white matter. Outer vessels and meninges were also removed. Preparations were pooled and ground using a Dounce homogenizer (first with the loose clearance pestle: $25-80 \mu \mathrm{m}$, then with the tight clearance pestle: 5-25 $\mu \mathrm{m}$ ) in HBSS $1 \mathrm{x}$ containing $10 \mathrm{mM}$ HEPES and $0.1 \%$ BSA. The resulting homogenate was mixed with $30 \%$ dextran $(v / \mathrm{v}$, molecular weight 100,000-200,000) in HBSS 1x supplemented with $10 \mathrm{mM}$ HEPES and $0.1 \%$ BSA. This suspension was centrifuged at $3000 \mathrm{~g}$ for $25 \mathrm{~min}$ at $4^{\circ} \mathrm{C}$. The neural component and the dextran layer were discarded and the pellet containing the vascular component was washed twice in cold PBS CMF and then separated into two equal parts by centrifugation at $1000 \mathrm{~g}$ for $7 \mathrm{~min}$ at $4^{\circ} \mathrm{C}$. The resulting pellets were resuspended either in RLT lysis buffer for RNA extraction or in RIPA lysis buffer for protein extraction.

\section{Quantitative RT-PCR}

RNA expression of drug transporter and tight junctionassociated genes was studied in brain tissues of 12-16 months old mice modelling $\mathrm{AD}$ and their healthy age-matched controls. Total RNA was extracted from HC, CX and CB tissue samples with TRI Reagent (Sigma). From microvessel samples, the RNA was extracted by RNeasy Mini Kit (Qiagen). After RNA extraction, the procedure was similar for both tissue and microvessel samples. Possible DNA residues were removed with DNA-free ${ }^{\mathrm{TM}}$ kit (Ambion). RNA concentration was measured with Nanodrop 1000 (Thermo Fisher Scientific) or NanoVue (GE Healthcare) spectrophotometer and $500 \mathrm{ng}$ (brain tissues) or $200 \mathrm{ng}$ (microvessels) of RNA was reverse-transcribed using random primers and $\mathrm{M}-\mathrm{MuLV}$ enzyme (Fermentas, Hanover, MD). In the quantitative realtime PCR, the ABI Prism 7500 instrument with TaqMan ${ }^{\circledR}$ Gene expression assays (Supplementary Table I) or SYBR Green chemistry and primers designed for each gene (Supplementary Table II) were used. Normalized expression was calculated with the QGene application (22) using betaactin as the reference gene. In the microvessel enriched fraction, a 2-fold difference was used as a threshold value and when a $>2$-fold difference was determined with the first batch, the results were confirmed with a second batch. Efficiency was calculated for each primer pair and a melting curve analysis was performed after amplification cycles, in order to check the specificity/purity of each amplification.

\section{Western Blotting}

After the capillary isolation procedure, the pellet was washed twice with cold PBS-CMF and then homogenized (polytron homogeniser: 2 times for $15 \mathrm{~s}$ at $11000 \mathrm{r} / \mathrm{min}$ on ice) in cold RIPA lysis buffer (Millipore, containing 0.5 M Tris-HCl, $\mathrm{pH}$ 7.4, $1.5 \mathrm{M} \mathrm{NaCl}, 2.5 \%$ deoxycholic acid, 10\% NP-40 and $10 \mathrm{mM}$ EDTA, supplemented with phosphatase and protease inhibitor cocktails (Sigma-Aldrich)). The protein concentration in each sample was determined by the method of Bradford (Bio-Rad). Then, 5-40 $\mu \mathrm{g}$ of proteins were electrophoresed on $4-15 \%$ Criterion XT sodium dodecyl sulphate (SDS)-polyacrylamide gel (P-gp/Abcb1, Rage, Lrpl) or 420\% Mini-Protean TGX Gel (Mrp4) (Bio-Rad) and subsequently electrotransferred to nitrocellulose membranes. Unspecific binding was blocked with 5\% skimmed milk in TBS, $0.1 \%$ Tween 20 and then incubated with primary antibody using following dilutions: Rage (Abcam) 1:2000, P-gp/ Abcbl (C219) (Genetex) 1:400, Lrp (5A6) (Santa Cruz) 1:200, Mrp4 (M41-10) (Santa Cruz) 1:200, $\beta$-actin (AC-15) (SigmaAldrich) 1:20,000, $\alpha$-tubulin (B-5-1-2) (Sigma-Aldrich) 1:8000 and $\beta$-tubulin (9F3) (Cell Signaling) 1:1000. Immunoreactivity was detected with HRP conjugated secondary antibodies (Goat anti-rat IgG (Santa Cruz) (1: 10,000), Goat anti-rabbit IgG (Dako) (1:2000) and Goat anti-mouse IgG (1:2000 for Dako and 1:7500 for Santa Cruz) and enhanced chemiluminescence (ECL) system.

\section{Pharmacokinetic In Vivo Microdialysis}

Microdialysis experiments were performed with 16-18 months old male APdE9 mice. To implant the guide cannulae (Brainlink B.V., the Netherlands) 2-3 days before the microdialysis experiment, the mice were anesthetized with 1-2\% isoflurane in $70 \% \mathrm{~N}_{2} \mathrm{O}$ and $30 \% \mathrm{O}_{2}$ (flow $300 \mathrm{ml} / \mathrm{min}$, induction $5 \%$ isoflurane). Lidocaine $(10 \mathrm{mg} / \mathrm{mL}$; Orion Corporation, Oulu, Finland) was used as a local anesthetic. Anesthetized mice were placed in a Kopf stereotaxic frame equipped with a DKI 921 mouse adapter (David Kopf Instr., Tujunga, CA, USA). The guide cannula was implanted into the right $\mathrm{HC}$ using following coordinates: A: $-3.1 \mathrm{~mm}, \mathrm{~L}:-2.7 \mathrm{~mm}, \mathrm{~V}:-1.3 \mathrm{~mm}$ and secured with cranial screws and dental cement. Carprofen ( $5 \mathrm{mg} / \mathrm{kg}$ s.c.; Vericore Ltd., Dundee, UK) and buprenorphine $(0.12 \mathrm{mg} / \mathrm{kg}$, s.c.; Schering-Plough, Belgium) were used for postoperative pain relief. Saline $(0.6 \mathrm{~mL}$ i.p.) was injected after surgery to maintain fluid balance.

Three hours before the start of the microdialysis experiment, the mice were transferred into microdialysis bowls (CMA120, CMA microdialysis, Solna, Sweden), and the microdialysis probe (membrane length $3 \mathrm{~mm}$, regenerated cellulose; cut-off $18 \mathrm{kDa}$; Brainlink B.V., the Netherlands) was inserted into the right $\mathrm{HC}$ through the guide cannula. The probe was connected to a rotating liquid swivel (375/D/ 
22QM, Instech Laboratories, Plymouth Meeting, PA, USA) and was perfused with Ringer fluid $(147 \mathrm{mM} \mathrm{NaCl}, 3 \mathrm{mM}$ $\mathrm{KCl}, 1.2 \mathrm{mM} \mathrm{CaCl}_{2}, 1.2 \mathrm{mM} \mathrm{MgCl}_{2}$ ) at a flow rate of $1.5 \mu \mathrm{l} /$ min. After a 120-min wash-out period, a 20 min baseline sample was collected and methotrexate $(50 \mathrm{mg} / \mathrm{kg}$ in a volume of $2.5 \mathrm{ml} / \mathrm{kg}$; Metoject, medac $\mathrm{GmbH}$ ) was given intravenously. Dialysate was collected for $240 \mathrm{~min}$ (12 samples), and the samples were frozen in liquid nitrogen and stored at $-70^{\circ} \mathrm{C}$. Terminal blood samples were collected by cardiac puncture and plasma was separated by centrifugation $\left(2000 \times \mathrm{g}\right.$ for $10 \mathrm{~min}$ at $\left.4^{\circ} \mathrm{C}\right)$, immediately fresh frozen on liquid nitrogen and stored at $-70^{\circ} \mathrm{C}$.

In vivo recovery was determined to estimate the true methotrexate concentration in the brain extracellular fluid in a separate experiment (wt $n=3$ and APdE9 $\mathrm{n}=3,13$ months) by using the retrodialysis method to calibrate the microdialysis probe. The basic procedure of in vivo microdialysis was performed as described above. After a 120-min wash-out period, a 20 min baseline sample was collected and then the Ringer solution was switched to a Ringer containing $200 \mathrm{ng} / \mathrm{mL}$ methotrexate. The microdialysis sample collection was continued for $120 \mathrm{~min}$ (6 samples). The in vivo recovery for methotrexate was calculated from the last three samples with the eq. $\mathrm{C}=(\mathrm{Cin}-\mathrm{Cout}) / \mathrm{Cin}$, where $\mathrm{R}$ is in vivo recovery of methotrexate, Cin is concentration of methotrexate in the perfusate and Cout is concentration of methotrexate in the dialysate. In vivo recovery values of $8 \pm 3 \%$ for APdE9 mice and $18 \pm 7 \%$ for WT mice were used to correct the dialysate concentrations.

\section{LC-MS/MS Analysis}

The microdialysis samples were analyzed for MTX concentration with an Agilent 1200 series liquid chromatograph and an Agilent 6410 Triple Quadrupole Mass Spectrometer with electrospray ionization. The column was a Poroshell 120 ECC18 $(50 \mathrm{~mm} \times 2.1 \mathrm{~mm}, 2.7 \mu \mathrm{m}$; Agilent Technologies, Santa Clara, CA) maintained at $40^{\circ} \mathrm{C}$ and a Rapid Resolution LC in-line filter ( $2 \mathrm{~mm}, 0.2 \mathrm{~mm}$; Agilent Technologies) was used for protecting the analytical column from possible contaminants. A binary mobile phase with a gradient elution was used. Solvent A was milliQ water with $0.1 \%$ formic acid (eluent additive for LC-MS, Fluka) and solvent $\mathrm{B}$ was acetonitrile (Sigma-Aldrich) with $0.1 \%$ formic acid. The gradient was performed as following: $5 \% \mathrm{~B}$ kept constant for $1 \mathrm{~min}$, increased to $90 \%$ for $5 \mathrm{~min}$, decreased to $5 \% \mathrm{~B}$ for $0.1 \mathrm{~min}$, and kept constant for $2.9 \mathrm{~min}$. Under these conditions, the total run time was $8 \mathrm{~min}$. The flow rate was $0.3 \mathrm{ml} / \mathrm{min}$ and the injection volume of Ringer fluid samples was $20 \mu \mathrm{l}$. The source parameters were: capillary voltage $3 \mathrm{kV}$, nebuliser 40 psi, gas temperature $300^{\circ} \mathrm{C}$, gas flow $8 \mathrm{l} / \mathrm{min}$. Data acquisition was done in the positive ion MRM mode using transitions $455.1 \rightarrow 308$ for MTX and $458.1 \rightarrow 311$ for the internal standard (deuterated MTX). Fragmentor voltages used for
MTX and the internal standard were $200 \mathrm{~V}$ and $160 \mathrm{~V}$, respectively. The collision energies were $38 \mathrm{~V}$ and $16 \mathrm{~V}$ for MTX and the internal standard, respectively. Agilent MassHunter Workstation Acquisition software (Data Acquisition for Triple Quadrupole Mass Spectrometer, version B.03.01) was used for data acquisition, whereas Quantitative Analysis (B.04.00) software was used for the data processing and analysis. The lower limit of quantification (LLOQ) was $0.05 \mathrm{ng} / \mathrm{ml}$ for Ringer fluid samples and $5 \mathrm{ng} /$ $\mathrm{ml}$ for plasma samples. The linearity of the calibration curve was evaluated by a quadratic regression analysis and the method was found to be selective, accurate, and precise over the calibration range. The calibration range of $0.05-500 \mathrm{ng} /$ $\mathrm{ml}$ was used for Ringer fluid samples and $5-1000 \mathrm{ng} / \mathrm{ml}$ for plasma samples. Within-run accuracy and precision were calculated from the results of the quality control samples at the three concentrations. The accuracies and precisions for quality control concentrations of $20 \%$ were considered acceptable.

\section{Data Analysis}

To evaluate differences in gene expression between brain tissues the statistical significance was tested with Kruskal-Wallis one way analysis of variance on Ranks followed by Dunn's Method for pairwise comparison (SigmaPlot 13.0).

The area under the concentration curve (AUC) values were determined using Phoenix ${ }^{\mathrm{TM}}$ WinNonlin ${ }^{\circledR}$ (Pharsight, Certara L.P., USA). In the statistical analysis of differences between AUG values, two-tailed t-test (SigmaPlot 13.0) was used.

\section{RESULTS}

\section{Gene Expression Profile of Drug Transporters and Tight Junction-Associated Proteins in Brain of AD Mouse Models}

\section{Efflux Transporters}

The expressions of $8 \mathrm{ABC}$ efflux transporters (Abcbla, Abcb1b, Abcc1-Abcc5, Abcg2) were compared between AD mouse models APdE9, Tg2576 and APP/PS1 (12-16 months old mice) and their healthy age-matched wt controls using brain samples comprising of brain parenchyma and BBB. In the APdE9 model, the greatest difference was detected for Abcblb gene, which had a 1.4-fold higher expression level in $\mathrm{AD} \mathrm{CX}$ and HC tissues when compared to wt (Fig. 1a). In Tg2576 mice, the differences between AD tissues and controls were $\leq 1.4$-fold (Fig. 1b) and in the APP/PS1 model, the differences were even smaller ( $\leq 1.3$-fold) (Fig. 1c), if Abcc2 was not taken into account. With respect to Abcc2, up to 2fold differences were detected, but statistical significance was not reached because of the high variation in Abcc2 expression 

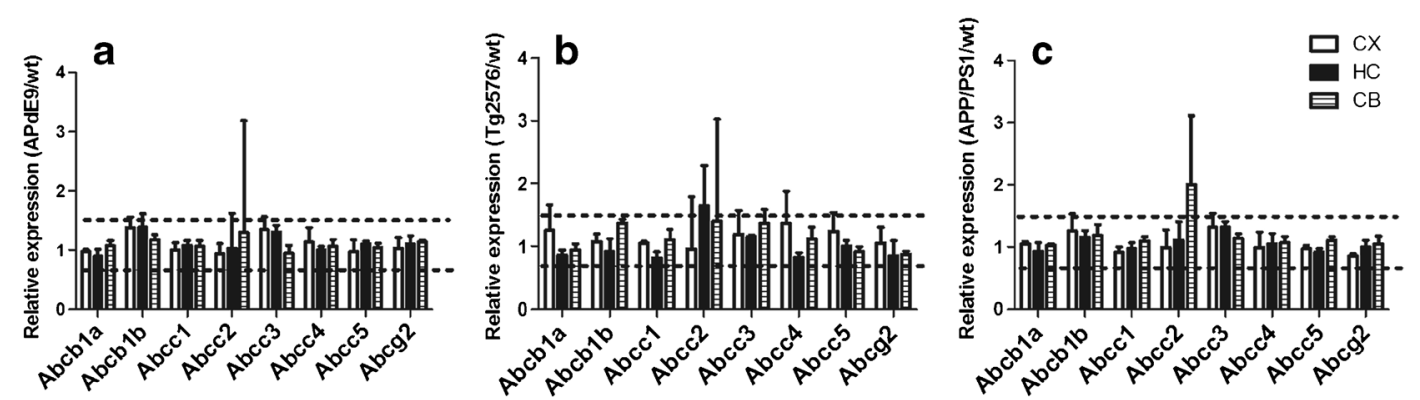

Fig. I Gene expression of Abc efflux transporters in the CX, HC and CB of male APdE9 (a), female Tg2576 (b) and female APP/PSI (c) mouse models expressed as relative to wt control mice (AD/wt) (mean $\pm \mathrm{sd}, n=3-5)$. The gene expression was normalized against the beta-actin house-keeping gene. The dotted line depicts 1.5-fold down- or up-regulation.

due to its very low expression levels. Overall, the gene expression profile of efflux transporters between these three $\mathrm{AD}$ models was similar. Differences between $\mathrm{AD}$ and wt were minor $(\leq 1.4$ fold) with the exception of Abcc2.

\section{Influx Transporters}

Gene expression of SLC influx transporters including L-type amino acid transporter (Slc7a5), peptide transporter (Slc15a2), organic anion and cation transporters (Slc22a2, Slc22a3, Slc22a5 and Slc22a8), Multidrug and toxin extrusion protein (Slc47al) and organic anion transporting polypeptides (Slcola4, Slco2bl and Slcolcl) was studied in the three AD mouse models (Fig. 2). More than 2-fold lower expression in $\mathrm{AD}$ samples compared to wt controls was observed for four transporters, namely Slc22a2 (HC of APdE9 and Tg2576), Slc22a3 (CB of Tg2576), Slc22a8 (HC of Tg2576) and Slc47al (HC of APdE9 and Tg2576). The highest difference was seen for Slc22a2, the expression of which in $\mathrm{HC}$ of $\mathrm{Tg} 2576$ mice was approximately one fifth of that in control and a similar trend was also seen in APdE9 (less than half than in controls). The Slc22a8 expression level in the HC of Tg2576 mice was one third of the control and similarly in APdE9, almost half of the control. In APP/PS1 brains, the differences between $\mathrm{AD}$ and control were in all cases $<1.5$ fold. Slc22a2 was expressed at a low level in all studied brain samples; likewise, the levels of Slc22a3 and Slc47al were low

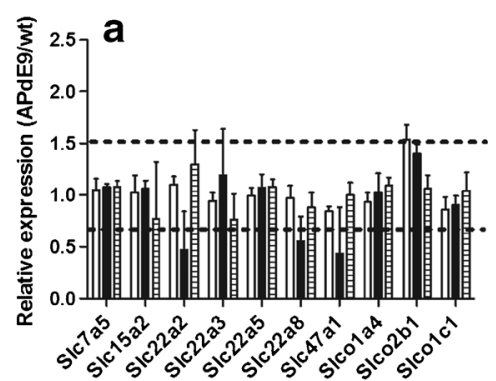

in certain tissues, thereby introducing high variability into the results for those genes.

\section{Tight Junction-Associated Proteins and Cell Markers}

Four genes (Ocln, Cldn3, Cldn5, Jam1) related to tight junctions were included in the study. Cldn3 expression in $\mathrm{HC}$ of Tg2576 and APdE9 mice was lower $(0.43 \pm 0.14$ and $0.61 \pm 0.30$, respectively) compared to wt control and similarly Jaml in HC of $\mathrm{Tg} 2576(0.61 \pm 0.11)$, but in other brain regions and animal models, the differences were smaller (Fig. 3). For the other tight junction-associated genes (Ocln, Cldn5), only minor differences were seen between AD and wt controls. However, with regard to the cell markers analyzed (Pecam1, Aifl, Rbfox3, Gfap), a clear upregulation of the astrocyte marker Gfap was detected. In the CX of APdE9, Tg2576 and APP/PS1 mice, the expression of Gfap was $3.5 \pm 0.2$-fold $(p=0.037)$, $2.27 \pm 1.13$-fold and $4.4 \pm 0.2$-fold $(p=0.029)$ higher, respectively, than in wt controls. In addition, in $\mathrm{HC}$, the $\mathrm{AD} / \mathrm{wt}$ ratio was elevated, i.e. it was $2.4 \pm 0.4$ in $\mathrm{APP} /$ PS1 and $2.3 \pm 0.2$ in APdE9. The microglial marker Aifl expression was upregulated only in APdE9 mice, with 1.6-fold and 1.5-fold higher expressions in $\mathrm{HC}$ and CX, respectively.

When the expression levels of 26 genes were compared between brain regions (CX, HC and $\mathrm{CB}$ ) of wt control mice, the differences were more prominent (Table I) and more than

Fig. 2 Gene expression of Slc influx transporters in the CX, HC and CB of male APdE9 (a), female Tg2576 (b) and female APP/PSI (c) mouse models expressed as relative to $w t$ control mice $(A D / w t)$ (mean $\pm s d, n=3-5)$. The gene expression was normalized against the beta-actin house-keeping gene. The dotted line depicts 1.5-fold down- or up-regulation. 

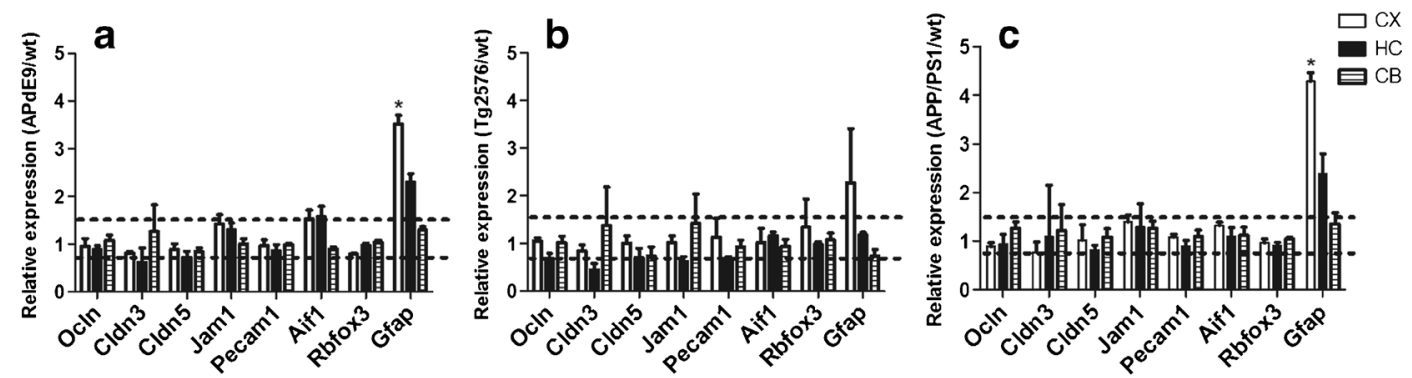

Fig. 3 Gene expression of tight junctions-associated proteins and cell markers in CX, HC and CB of male APdE9 (a), female Tg2576 (b) and female APP/PSI (c) AD models expressed as relative to $w t$ control mice $(A D / w t)($ mean $\pm s d, n=3-5)$. The gene expression was normalized against the beta-actin house-keeping gene. The dotted line depicts I.5-fold down- or up-regulation. *indicates significant difference between AD and wt $(p<0.05)$.

2-fold differences were observed for 20 genes. Only Slcolcl was equally expressed in all three brain regions. Ocln expression was 5-7 -fold higher in $\mathrm{CB}$ than in $\mathrm{CX}$, whereas in $\mathrm{CX}$, the expression of Slc22a3 was $\geq 5$-fold higher than in $\mathrm{CB}$ and HC. Interestingly, the expression of Abcc1, Slc7a5, Slc22a5, Slc47al, Cldn5 and Jaml was higher (>2-fold) in CB than in CX.

The differences between brain regions were rather similar among all three wt control strains. Since only minor differences were detected between $\mathrm{AD}$ and wt mice, these results are mostly comparable also in $\mathrm{AD}$ mice models.

\section{Gene and Protein Expression Profile in Brain Microvessel Enriched Fraction of APdE9 Mice}

The expression of 35 genes was studied in enriched fraction of microvessels isolated from the cortices of 5-12 weeks old APdE9 mice and age-matched controls. In the case of 11 genes, there was a more than 2-fold difference in the expression level between $\mathrm{AD}$ and wt (Table II). Only one gene, Slc2a1, was upregulated by 2-fold in AD; for 10 genes, the $\mathrm{AD} /$ wt ratio was $<0.5$. For the endothelial markers Pecam1 and Cdh5, the ratio was in the range 0.31-0.36. Efflux transporters Abcbla, Abcc4 and Abcg2

Table I Comparison of gene expression between brain regions in three wt strains (healthy control of each AD mice model i.e. male APdE9, female Tg2576 and female APP/PSI)

\begin{tabular}{|c|c|c|c|c|c|c|c|c|c|}
\hline & $\begin{array}{l}\text { HC/CX } \\
\text { APdE9 }\end{array}$ & $\begin{array}{l}\mathrm{HC} / \mathrm{CX} \\
\mathrm{Tg} 2576\end{array}$ & $\begin{array}{c}\text { HC/CX } \\
\text { APP/PSI }\end{array}$ & $\begin{array}{l}\text { CB/CX } \\
\text { APdE9 }\end{array}$ & $\begin{array}{c}\text { CB/CX } \\
\text { Tg2576 }\end{array}$ & $\begin{array}{c}\text { CB/CX } \\
\text { APP/PSI }\end{array}$ & $\begin{array}{l}\text { CB/HC } \\
\text { APdE9 }\end{array}$ & $\begin{array}{l}\text { CB/HC } \\
\text { Tg2576 }\end{array}$ & $\begin{array}{c}\text { CB/HC } \\
\text { APP/PSI }\end{array}$ \\
\hline Abcb1a & $0.88 \pm 0.22$ & $0.86 \pm 0.20$ & $0.73 \pm 0.15$ & $1.72 \pm 0.14$ & $1.67 \pm 0.29$ & $1.74 \pm 0.10$ & $1.94 \pm 0.16$ & $1.95 \pm 0.34$ & $2.37 \pm 0.13$ \\
\hline Abcb1b & $1.05 \pm 0.20$ & $0.91 \pm 0.18$ & $1.13 \pm 0.19$ & $0.78 \pm 0.11$ & $0.48 \pm 0.12 *$ & $0.69 \pm 0.07$ & $0.75 \pm 0.11$ & $0.53 \pm 0.13$ & $0.61 \pm 0.06$ \\
\hline Abcc1 & $.95 \pm 0.05$ & $0.81 \pm 0.18$ & $0.81 \pm 0.01$ & $2.37 \pm 0.46$ & $2.16 \pm 0.22$ & $2.3 \pm 0.18$ & $2.5 \pm 0.48$ & $2.65 \pm 0.27$ & $2.86 \pm 0.22$ \\
\hline Abcc2 & $12 \pm 0.66$ & $0.36 \pm 0.16$ & $0.50 \pm 0.17$ & $1.15 \pm 0.84$ & $0.52 \pm 0.59$ & $0.63 \pm 0.58$ & $1.03 \pm 0.75$ & $1.46 \pm 1.65$ & $1.26 \pm 1.16$ \\
\hline Abcc3 & $0.90 \pm 0.09$ & $0.63 \pm 0.13$ & $0.76 \pm 0.04$ & $0.61 \pm 0.06$ & $0.47 \pm 0.27$ & $0.65 \pm 0.05$ & $0.68 \pm 0.07$ & $0.74 \pm 0.43$ & $0.85 \pm 0.06$ \\
\hline Abcc4 & $1.13 \pm 0.13$ & $0.97 \pm 0.21$ & $0.94 \pm 0.09$ & $1.97 \pm 0.05$ & $1.69 \pm 0.31$ & $1.93 \pm 0.27$ & $1.75 \pm 0.04$ & $1.75 \pm 0.32$ & $2.06 \pm 0.29$ \\
\hline Abcc5 & $0.68 \pm 0.06$ & $0.72 \pm 0.05$ & $0.74 \pm 0.05$ & $1.37 \pm 0.15$ & $1.60 \pm 0.21$ & $1.46 \pm 0.05$ & $2.01 \pm 0.23$ & $2.22 \pm 0.30$ & $1.97 \pm 0.06$ \\
\hline Abcg2 & $0.87 \pm 0.15$ & $0.81 \pm 0.2$ & $0.89 \pm 0.09$ & $1.31 \pm 0.12$ & $1.09 \pm 0.17$ & $1.35 \pm 0.27$ & $1.52 \pm 0.14$ & $1.35 \pm 0.21$ & $1.51 \pm 0.30$ \\
\hline Slc7a5 & $85 \pm 0.15$ & $0.79 \pm 0.17$ & $0.78 \pm 0.09$ & $2.21 \pm 0.17$ & $2.01 \pm 0.41$ & $2.05 \pm 0.16$ & $2.58 \pm 0.20$ & & $2.64 \pm 0.21$ \\
\hline Slc15a2 & $0.93 \pm 0.08$ & $0.96 \pm 0.31$ & $1.09 \pm 0.18$ & $1.98 \pm 0.10$ & $1.66 \pm 0.83$ & $5.54 \pm 0.82$ & $2.14 \pm 0.11$ & $1.74 \pm 0.86$ & $5.09 \pm 0.75$ \\
\hline Slc22a2 & $1.60 \pm 1.09$ & $1.80 \pm 1.26$ & $0.97 \pm 0.41$ & $1.01 \pm 0.26$ & $0.71 \pm 0.30$ & $0.88 \pm 0.16$ & $0.63 \pm 0.16$ & $0.40 \pm 0.17$ & $0.90 \pm 0.17$ \\
\hline Slc22a3 & $0.15 \pm 0.09$ & $0.19 \pm 0.05$ & $0.12 \pm 0.05$ & $0.18 \pm 0.16$ & $0.11 \pm 0.01$ & $0.06 \pm 0.05^{*}$ & $1.21 \pm 1.06$ & $0.61 \pm 0.07$ & $0.52 \pm 0.40$ \\
\hline Slc22a5 & $0.91 \pm 0.11$ & $1.14 \pm 0.23$ & $1.00 \pm 0.11$ & $2.09 \pm 0.16$ & $2.46 \pm 0.50$ & $2.27 \pm 0.20$ & $2.29 \pm 0.18$ & $2.16 \pm 0.44$ & $2.28 \pm 0.20$ \\
\hline Slc22a8 & $1.54 \pm 0.78$ & $1.27 \pm 0.69$ & $0.92 \pm 0.46$ & $1.92 \pm 0.30$ & $1.77 \pm 0.20$ & $1.20 \pm 0.13$ & $1.24 \pm 0.19$ & $0 \pm 0.15$ & \pm 0.14 \\
\hline Slc47a1 & $0.90 \pm 0.77$ & $1.29 \pm 0.79$ & $0.85 \pm 0.64$ & $2.70 \pm 0.84$ & $2.34 \pm 1.28$ & $2.10 \pm 0.30$ & $3.00 \pm 0.94$ & $1.82 \pm 1.00$ & $2.48 \pm 0.36$ \\
\hline Slco1a4 & $1.12 \pm 0.17$ & $0.95 \pm 0.43$ & $0.92 \pm 0.12$ & $2.09 \pm 0.10$ & $1.48 \pm 0.36$ & $1.95 \pm 0.13$ & $1.86 \pm 0.09$ & $1.55 \pm 0.38$ & $2.12 \pm 0.14$ \\
\hline Slco2b1 & $0.93 \pm 0.08$ & 0.82 & 0.93 & $0.89=$ & \pm 0.19 & & \pm 0.14 & 0.23 & \pm 0.05 \\
\hline Slco1c1 & $0.89 \pm 0.16$ & $0.78 \pm 0.11$ & $0.83 \pm 0.09$ & $1.17 \pm 0.21$ & $1.14 \pm 0.12$ & $1.08 \pm 0.19$ & $1.33 \pm 0.23$ & $1.45 \pm 0.29$ & $1.30 \pm 0.23$ \\
\hline Ocln & $1.76 \pm 0.15$ & $2.55 \pm 0.62$ & $1.74 \pm 0.15$ & $5.64 \pm 0.16$ & $7.25 \pm 0.75^{*}$ & $5.37 \pm 0.40$ & $3.20 \pm 0.09$ & $2.84 \pm 0.30$ & $3.09 \pm 0.23$ \\
\hline Cldn3 & $1.30 \pm 1.04$ & $1.87 \pm 1.94$ & $1.09 \pm 0.16$ & $1.49 \pm 0.80$ & $0.89 \pm 0.50$ & $1.39 \pm 0.94$ & $1.14 \pm 0.62$ & $0.47 \pm 0.27$ & $1.28 \pm 0.87$ \\
\hline Cldn5 & $1.24 \pm 0.25$ & $1.14 \pm 0.30$ & $0.88 \pm 0.33$ & $1.88 \pm 0.17$ & $2.12 \pm 0.84$ & $1.43 \pm 0.28$ & $1.51 \pm 0.13$ & $1.86 \pm 0.74$ & $1.62 \pm 0.32$ \\
\hline Jam1 & $1.05 \pm 0.18$ & $1.30 \pm 0.96$ & $0.99 \pm 0.27$ & $2.38 \pm 0.25^{*}$ & $3.78 \pm 1.54$ & $1.65 \pm 0.29$ & $2.27 \pm 0.24$ & $2.91 \pm 1.19$ & $1.67 \pm 0.30$ \\
\hline Pecam1 & $1.11 \pm 0.29$ & $1.06 \pm 0.35$ & $0.99 \pm 0.27$ & $1.86 \pm 0.09$ & $1.44 \pm 0.44$ & $1.73 \pm 0.17$ & $1.67 \pm 0.08$ & $1.36 \pm 0.42$ & $1.74 \pm 0.17$ \\
\hline Aif1 & $0.76 \pm 0.08$ & $0.72 \pm 0.14$ & $0.84 \pm 0.11$ & $0.80 \pm 0.14$ & $0.53 \pm 0.18$ & $0.51 \pm 0.02$ & $1.06 \pm 0.18$ & $0.74 \pm 0.25$ & $0.60 \pm 0.02$ \\
\hline Rbfox3 & $0.63 \pm 0.08$ & $0.73 \pm 0.02$ & $0.75 \pm 0.02$ & $1.59 \pm 0.30$ & $2.18 \pm 0.16$ & $2.09 \pm 0.23$ & $2.54 \pm 0.48$ & $2.97 \pm 0.22$ & $2.80 \pm 0.30$ \\
\hline Gfap & $2.18 \pm 0.29$ & $2.23 \pm 0.50^{*}$ & $2.38 \pm 0.25$ & $1.68 \pm 0.16$ & $1.85 \pm 0.22$ & $2.67 \pm 0.45$ & $0.77 \pm 0.07$ & $0.83 \pm 0.10$ & $1.12 \pm 0.19$ \\
\hline
\end{tabular}
Results are expressed $\mathrm{HC} / \mathrm{CX}, \mathrm{CB} / \mathrm{CX} \mathrm{OR} \mathrm{CB} / \mathrm{HC}$ ratio (mean $\pm \mathrm{sd}, \mathrm{n}=3-5$ ). Yellow color indicates $\geq 1.5$-fold and green color $\geq 2$-fold differences between brain regions. ${ }^{*}=p<0.05$ 
had $73 \%, 60 \%$ and $55 \%$ lower expression levels, respectively, in $\mathrm{AD}$ than in wt. A similar trend was observed in case of the expression of the influx transporters Slc22a8 $(55 \%)$ and Slcola4 (61\%), beta-amyloid peptide receptor Ager (Rage) (65\%) and tight junction-associated genes occludin $(60 \%)$ and claudin $5(64 \%)$.

Results were normalized against beta-actin, which showed stable expression between $\mathrm{AD}$ and wt samples. Since the amount of RNA was limited, the replicate measurements were focused on genes with moderate or high expression and/or where a difference between $\mathrm{AD}$ and wt was detected in the first measurement.
The microvessel enriched fraction was used also to study the protein expression of the main receptors for amyloid-beta peptide, Rage and Lrp1, with the efflux transporters Mdr1 and Mrp4 showing lower gene expression in $\mathrm{AD}$ than in wt mice. According to the results of immunoblotting, the expression of these proteins did not differ significantly $(\leq 1.5$-fold $)$ between $\mathrm{AD}$ and wt samples (Fig. 4).

\section{Distribution of Methotrexate into Brain in APdE9 Mice}

To assess the effect of $\mathrm{AD}$ pathology on efflux transporter function in vivo, methotrexate was selected as a model drug for the

Table II Comparison of Gene Expression Levels between Brain Microvessels Isolated from Cortices of Female AD Mice (APdE9) and their wt Controls

\begin{tabular}{|c|c|c|}
\hline \multicolumn{3}{|c|}{ ATP-binding cassette (ABC) transporters } \\
\hline Gene & Protein & Ratio of $A D / w^{a}$ \\
\hline Abcbla & Multidrug resistance protein la (Mdr la) & $0.258-0.283$ \\
\hline Abcblb & Multidrug resistance protein Ib (Mdrlb) & 0.537 \\
\hline Abccl & Multidrug resistance-associated protein I (Mrp I) & 0.758 \\
\hline Abcc2 & Multidrug resistance-associated protein 2 (Mrp2) & 0.677 \\
\hline Abcc3 & Multidrug resistance-associated protein 3 (Mrp3) & 1.011 \\
\hline Abcc4 & Multidrug resistance-associated protein 4 (Mrp4) & $0.397 \mid-0.3973$ \\
\hline Abcc5 & Multidrug resistance-associated protein 5 (Mrp5) & $0.588-0.668$ \\
\hline Abcg2 & Breast cancer resistance protein (Bcrp) & $0.436-0.457$ \\
\hline \multicolumn{3}{|c|}{ Solute carriers (SLCS) } \\
\hline Slc2al & Glucose transporter I (GlutI) & $1.803-2.230$ \\
\hline Slc5a7 & High affinity choline transporter I (ChtI) & $1.173-1.653$ \\
\hline Slc7a5 & L-type amino acid transporter I (Latl) & $0.696-0.943$ \\
\hline Slc $15 \mathrm{a} 2$ & Peptide transporter 2 (Pept2) & $0.766-0.913$ \\
\hline Slc|6al & Monocarboxylate transporter I (Mctl) & $0.620-0.657$ \\
\hline Slc22a2 & Organic cation transporter 2 (Oct2) & 1.161 \\
\hline Slc22a3 & Organic cation transporter 3 (Oct3) & 0.990 \\
\hline Slc22a5 & Organic cation/carnitine transporter 2 (Octn2) & 0.626 \\
\hline Slc22a8 & Organic anion transporter 3 (Oat3) & $0.414-0.495$ \\
\hline Slc29al & Equilibrative transporter I (EntI) & $0.941-1.03$ \\
\hline Slc47al & Multidrug and toxin extrusion protein I (Matel) & 0.543 \\
\hline Slcola4 & Organic anion transporting polypeptide la4 (Oatp la4) & $0.369-0.405$ \\
\hline Slco2bl & Organic anion transporting polypeptide $2 \mathrm{~b} \mathrm{l}$ (Oatp2bl) & $0.7 \mid 4-0.726$ \\
\hline Slcolcl & Organic anion transporting polypeptide $\mid \mathrm{cl}($ Oatp $\mid \mathrm{cl})$ & $0.525-0.563$ \\
\hline \multicolumn{3}{|c|}{ Transport of beta-amyloid } \\
\hline & Full name & \\
\hline Lrp $\mid$ & Low density lipoprotein receptor-related protein I & $0.960-0.964$ \\
\hline Ager & Advanced glycation end product-specific receptor (Rage) & $0.300-0.400$ \\
\hline \multicolumn{3}{|c|}{ Tight junction-associated proteins } \\
\hline Odn & Occludin & $0.362-0.431$ \\
\hline Cldn I & Claudin I & |.079-1.334 \\
\hline Cldn3 & Claudin 3 & 1.052 \\
\hline Cldn5 & Claudin 5 & $0.308-0.410$ \\
\hline Tjpl & Tight junction protein ZO-I & $0.555-0.646$ \\
\hline Fllr & Junctional adhesion molecule $\mathrm{A}(\mathrm{Jam}-\mathrm{A})$ & $0.59 \mid-0.666$ \\
\hline \multicolumn{3}{|l|}{ Cell markers } \\
\hline & Full name/Cell type & \\
\hline Pecam l & Platelet/endothelial cell adhesion molecule I/Endothelial & $0.324-0.363$ \\
\hline Cdh5 & Cadherin-5/Endothelial & $0.306-0.354$ \\
\hline Aifl & Allograft inflammatory factor I/Microglial & $0.826-0.898$ \\
\hline Gfap & Glial fibrillary acidic protein/Astrocytic & $1.07-1.09$ \\
\hline Rbfox3 & RNA binding protein, fox-I homolog (C. elegans) 3/Neuronal & 1.243 \\
\hline
\end{tabular}

${ }^{a}$ When results are expressed as range, two replicate samples were used. Otherwise the results are based on one sample of isolated microvessels. Each sample is a pool from brain microvessels of 5 mice 
brain microdialysis studies since it has been previously shown to be effluxed by both Mrp4 and Bcrp in a similar study conducted in Mrp4 and Bcrp knock-out mice (23). Unbound extracellular methotrexate levels in hippocampus were 9-fold higher in APdE9 mouse than the corresponding values in wt in the 20 min fraction after drug administration (Fig. 5), but the difference diminished later. The brain methotrexate exposure $\left(\mathrm{AUC}_{0-\infty}\right)$ was 2.7 -fold higher in APdE9 than in $\mathrm{wt}$ $(p=0.013)$ mice and the difference was even greater, 2.9-fold $(p=0.006)$, within the first $60 \mathrm{~min}\left(\mathrm{AUC}_{0-60}\right)$ (Table III). Total plasma concentration was measured after intravenous injection of methotrexate from separate mice (wt $n=6$ and APdE9 $n=5-6,17$ months). The plasma concentrations at 10, 30 and $60 \mathrm{~min}$ were $52.7 \pm 7,14.0 \pm 7.2$ and $5.9 \pm 1.1 \mu \mathrm{g} / \mathrm{ml}$ (mean $\pm \mathrm{sd}$ ) in APdE9 and 58.4 \pm 16, $14.1 \pm 4.5$ and $6.6 \pm 2.6 \mu \mathrm{g} / \mathrm{ml}$ in wt mice, respectively.

\section{DISCUSSION}

Transporters and tight junctions of the $\mathrm{BBB}$ are crucial for the maintenance of brain homeostasis. Neurodegenerative diseases, such as $\mathrm{AD}$, alter the function of the BBB and are therefore likely to change drug distribution into the brain (24). In this study, the expression of Abc and Slc transporters relevant in pharmacokinetics and tight junction-associated proteins in the brains of three AD mouse models, APdE9, Tg2576 and APP/ PS1 were investigated. We focused on genes that are known to be expressed in brain/BBB. Brain samples were dissected from $>12$ months old animals having clear pathological signs of the disease in their brain i.e. amyloid beta plaques and gliosis. We used APP and APP/PS1 mutant mouse lines considered to be $\mathrm{AD}$ models of $\mathrm{A} \beta$ pathology rather than $\mathrm{AD}$ models fully addressing the clinical presentation of AD. The expression levels of the studied genes in $\mathrm{AD}$ models were close to their healthy age-matched controls and the observed differences were minor

\begin{tabular}{|c|c|c|c|c|}
\hline & wt & $A D$ & & $\begin{array}{c}\text { Mean fold change } \\
A D / w t\end{array}$ \\
\hline Rage & 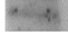 & $m=$ & $42 \mathrm{kDa}$ & $0.97 \pm 0.27$ \\
\hline$\beta$-Tubulin & $=$ & $\longrightarrow$ & $55 \mathrm{kDa}$ & \\
\hline Lrp1 & $\ldots$ & & $75 \mathrm{kDa}$ (expected $84 \mathrm{kDa}$ ) & $0.92 \pm 0.03$ \\
\hline$\beta$-Actin & - & $\longrightarrow$ & $42 \mathrm{kDa}$ & \\
\hline Mdr1 & & & $141 \mathrm{kDa}$ & $0.92 \pm 0.07$ \\
\hline$\beta$-Actin & 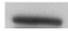 & $\longrightarrow$ & $42 \mathrm{kDa}$ & \\
\hline
\end{tabular}

\begin{tabular}{llc|}
\hline Mrp4 & $159 \mathrm{kDa}$ & $1.5 \pm 0.36$ \\
$\alpha$-Tubulin & $42 \mathrm{kDa}$ & \\
\hline
\end{tabular}

Fig. 4 Expression of Rage, Lrpl, Mdrl and Mrp4 proteins in microvessel enriched fraction isolated from cortices of female APdE9 (AD) and wt mouse and detected by Western blotting. For Rage, Lrp I and Abcb I $40 \mu \mathrm{g}$ of total protein were used, the corresponding value for Mrp4 was $5 \mu$ g. Mean fold change \pm SEM (AD/Wt) was calculated based on three replicate blots

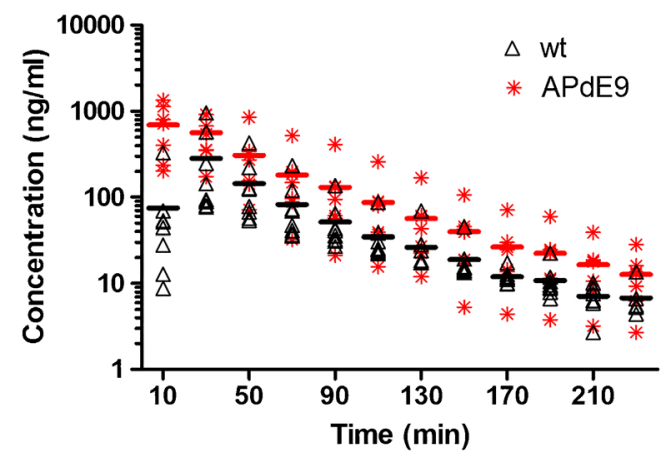

Fig. 5 Unbound extracellular methotrexate levels in the hippocampus of male APdE9 mice (AD) $(n=7)$ and wt controls $(n=8)$ after i.v. injection at $50 \mathrm{mg} / \mathrm{kg}$. Microdialysis samples were collected as $20 \mathrm{~min}$ fractions. LLOQ was $0.05 \mathrm{ng} / \mathrm{ml}$

(mostly less than 1.5-fold change) with the exception of the astrocyte cell marker, Gfap. This was expected since upregulation of Gfap due to an increase in the numbers of reactive astrocytes is an early and common sign in various models of neurodegeneration and brain diseases, and is also observed in transgenic $\mathrm{AD}$ mice (25). Furthermore, the expression of the microglial activation marker, Aifl, was elevated (about 1.5fold) in APdE9 mice in line with extensive data revealing neuroinflammation as a characteristic of AD.

Comparison of gene expression of transporters and tight junction-associated proteins between brain regions showed more than 2-fold differences for 21 genes in wt mice. For 14 genes, a higher expression level was observed in CB in comparison to $\mathrm{CX}$ or $\mathrm{HC}$. We detected a $>5$-fold difference between brain regions in gene expression of organic cation transporter Slc22a3 and the tight junction-associated protein, occludin. Such large differences in gene expression should reflect protein expression and functionality. In the literature, the data regarding regional variability of brain drug transporters is sparse and scattered. The highest Mdrl activity has been proposed for CB by a combinatory mapping approach and PET studies in rats $(26,27)$. These observations are in accordance with our data as Abcbla is the major form in brain. However, in another study, Mdrl mediated efflux activity of loperamide was highest in cerebral CX and midbrain regions when assessed by in situ brain perfusion in mice (28). Kannan et al. stated that there was equal BCRP density

Table III Brain Exposure to Methotrexate in Male APdE9 Mice (AD) and their wt Controls After i.v. Injection at $50 \mathrm{mg} / \mathrm{kg}$. AUC Calculated from Whole Concentration-Time Curve $\left(\mathrm{AUC}_{0-\infty}\right)$ and First $60 \mathrm{~min}\left(\mathrm{AUC}_{0-60}\right)$ are Presented (mean \pm SEM, $n=7-8)$

\begin{tabular}{lll}
\hline & AD & wt control \\
\hline $\mathrm{AUC}_{0-\infty}(\mathrm{ng} \times \mathrm{min} / \mathrm{ml})$ & $40178 \pm 7587 *$ & $15107 \pm 4765$ \\
$\mathrm{AUC}_{0-60}(\mathrm{ng} \times \mathrm{min} / \mathrm{ml})$ & $27485 \pm 4167 * *$ & $9507 \pm 3604$ \\
\hline${ }^{*} \mathrm{p}<0.05$ vs. wt control value & \\
$* * *_{p}<0.0$ I vs. wt control value &
\end{tabular}


between brain regions, which is also in line with our results (13). The high regional variability in transporter expression may perhaps be explained by the higher capillary density in certain brain region or the variation in the relative amount of each cell type. Previously, brain capillary density has been determined with the vascular volume marker, inulin, with a 3.7-fold difference being observed between brain regions (28). This high variation between brain areas can affect the regional distribution of drugs in brain, but more information about transporter expression at the cell type level will be needed to estimate the effect of regional variability on brain pharmacokinetics and access of drugs to their target site.

The endothelial cells of the BBB and tight junctions expressed between these cells form the physical barrier for brain distribution of drugs. Since the brain microvessels comprise only $0.1 \%$ of brain weight and brain tissue contains many cell types (endothelial cells, astrocytes, microglial cells, neurons and pericytes), the alterations in gene and protein expression occurring solely in the microvessel endothelial cells can be interfered by other cell types. Therefore, further studies to reveal $\mathrm{AD}$-induced changes in BBB protein expression were conducted by using brain microvessels isolated from APdE9 mice. The isolation of a microvessel enriched fraction is feasible only in young mice ( $\leq 12$ weeks), whose brain pathology of $\mathrm{AD}$ is still developing. The normalized expressions of endothelial markers, Pecaml and Cdh5, were about 3-fold lower in APdeE9 compared to their healthy control mice, suggesting that APP and PSEN1 mutations may considerably affect the brain vasculature already during development or in young adulthood. Both increased and decreased vascular densities have been reported in $\mathrm{AD}(29)$.

The gene expression of Abcbla was downregulated in the microvessel enriched fraction which is in line with the earlier reports from AD patients and animal models $(8,10)$. Furthermore, Abcc4 and Abcg2 were downregulated. In order to assess the effect of $\mathrm{AD}$ pathology on efflux transporter function, MTX was selected as a model drug, because it has been previously demonstrated to cross the BBB via Mrp4 and Bcrp in a brain microdialysis study conducted in Mrp4 and Bcrp knock-out mice (23). Methotrexate is also a substrate for MDR1, OAT and OATP transporters (30-34). Since Abcbla (Mdrla), Slac22a8 (Oat3) and Slcola4 (Oatpla4) were also downregulated in the microvessel enriched fraction, it is possible that these transporters participate in the distribution of methotrexate into the brain. As far as we are aware, this is the first study where AD-induced changes in brain unbound extracellular drug concentrations have been studied by pharmacokinetic microdialysis in the context of transporter function.

Brain microdialysis revealed that methotrexate gained faster access into the brain in 16-18 months old APdE9 mice after drug administration but the difference $v s$. wt controls diminished later. This finding may reflect alterations in the active transport in BBB or otherwise compromised BBB. Identification of functionally altered transporter $(\mathrm{s})$ is challenging due to overlapping substrate specificities and would require experiments with inhibitors. The consequences of BBB disruption, even when local or transient, can be harmful for the homeostasis of brain. $A \beta$ has been reported to compromise $\mathrm{BBB}$ tight junction proteins and thus BBB integrity in human amyloid precursor protein transgenic mice (35) and human apoE4 transgenic mice (36). Generally, in tumor-bearing rats, a compromised $\mathrm{BBB}$ has been shown to increase brain extracellular MTX levels shortly after drug administration (37). However, Bien-Ly et al. (2015) reported recently that brain access of antibodies and radiotracers was not significantly altered in AD mouse models (38). Cheng et al. (2010) also reported that brain penetration of some small-molecule drugs was unaltered in AD-related animal models and Mehta et al. (2013) even found decreased brain uptake of transcellular permeability markers (diazepam and propranolol) in the 3xTg model possibly due to thickening of the basement membrane $(16,39)$. Furthermore, imaging studies with $\mathrm{AD}$ patients have not found convincing evidence that $\mathrm{AD}$ alone, without a vascular component, causes BBB disruption (2). These discrepancies both in experimental models of $\mathrm{AD}$ and patients may partly be due to variation in the degree of $\mathrm{AD}$ pathology and the characteristics of the model drugs. Accumulation of $\mathrm{A} \beta$ plaques within the extracellular space, severe shrinkage of cerebral cortex and hippocampus, and an increase in the size of the ventricles in $\mathrm{AD}$ brains may affect the distribution of drugs in brain tissue. For a hydrophilic drug like methotrexate $\left(\log \mathrm{D}_{\mathrm{pH} \text { 7.4 }}-5.22\right.$, Chemspider, predicted using ACD/Labs), a smaller volume of extracellular fluid can lead to higher initial drug concentration in $\mathrm{AD}$ mice after a single systemic dose.

No significant differences were detected between $<3$ month old APdE9 mice and their controls at the protein level in the expression of Mdr1, Mrp4, Rage and Lrpl in the microvessel enriched fraction. Earlier, Hartz et al. (2010) demonstrated that Mdr1 expression was decreased by approximately 60\% and efflux of Mdrl substrate NBD-CSA was reduced by $70 \%$ in brain capillaries of Tg2576 mice (8). Recently, Do et al. (2016) stated that Abcb1 and Abcg2 expressions in the brain capillary fraction of another $\mathrm{AD}$ model, $3 \mathrm{xTg}-\mathrm{AD}$ were upregulated by 1.7 -fold at 18 months of age, although younger mice (3 and 6 months) did not display significant changes (17). With the same AD model, Mehta et al. reported that cortical or hippocampal uptake of three Mdrl substrates, digoxin, loperamide and verapamil, was not significantly altered in 18-20 month old 3xTg-AD mice (16). However, Mdrl expression showed variability between replicates, ranging from a $42 \%$ reduction to no difference in $3 \mathrm{xTg}-\mathrm{AD}$ compared to wt controls. These results demonstrate that alterations in efflux proteins, induced by $\mathrm{AD}$-causing mutations, are minor in animal models but comparable to those encountered in human studies.

The expression level of transporters affects the maximum velocity of transport $\left(\mathrm{V}_{\max }\right)$ and therefore, it can be assumed to reflect in transport function. A decrease in the transporter 
expression is comparable to the inhibition kinetics of active transport, where the degree of inhibition increases with inhibitor concentration (40). Should efflux transporter expression decrease by $50 \%$, this would cause at maximum a 2 -fold increase in the steady state drug concentration in the brain, assuming that the drug passes through the BBB exclusively via this specific transporter. Similarly, a $67 \%$ decline in expression would cause at maximum a 3 -fold and an $80 \%$ decline would evoke a maximum of a 5 -fold increase in brain drug concentration at steady state. If we consider the clinical relevance of alterations detected in $\mathrm{AD}$ patients, mostly 2-fold or smaller alterations for MDR1 have been observed. For instance, when the activity of MDR 1 was studied with PET imaging, the binding potential of verapamil was found to be modestly increased in $\mathrm{AD}$ patients (2.18 \pm 0.25$)$ compared to healthy controls $(1.77 \pm 0.41)$ (14). In addition, the expression of MDR 1 was $25 \%$ lower in the blood vessels of $\mathrm{AD}$ patients than age-matched controls when hippocampal sections were studied by immunofluorescence (10). Accordingly, when Kannan et al. recently studied transporter density in the vascular space, they found that MDR 1 global density was 53\% lower in the temporal $\mathrm{CX}$ of $\mathrm{AD}$ patients as compared to controls, and in capillaries near to $A \beta$ deposits, the MDR 1 density was locally decreased by $35 \%$ (13). Our present results with $\mathrm{AD}$ models are in line with these observations. Therefore, in order that a detected approximately 2-fold change in expression level should be clinically significant, the drug should have an extremely narrow therapeutic level and adverse effects in brain should be the dose-limiting factor, an extremely rare situation for clinically used drugs (40). It should be kept in mind that in addition to the expression level, transporter functionality is also dependent on other factors such as post-translational modifications and changes in membrane composition, which may change in Alzheimer's disease and affect binding affinity and transport activity. Furthermore, binding to plasma proteins is an important factor influencing drug distribution into the brain since only unbound drug is able to cross the endothelial cell barrier. Disease states can change the plasma protein binding, but thus far, no significant changes in plasma protein content have been observed in $\mathrm{AD}$ patients. In addition to the influence of disease, other factors such as age and sex may affect transporter expression $(41,42)$. However, in this study, we used age-matched controls of the same gender in order to assess the effect of $\mathrm{AD}$ on drug transporters.

In conclusion, transporter expression varied significantly between brain areas in both transgenic $\mathrm{AD}$ mice and wt mice. However, disease-induced alterations in transporter expression were low in all studied transgenic $\mathrm{AD}$ mouse models, which accords with the current knowledge on diseaseinduced changes in AD patients. Decreased expression of some transporters and tight junction-associated proteins in brain microvessel fraction of APdE9 mice as well as more rapid brain access of MTX in APdE9 mice indicate that AD pathology may contribute to the BBB functionality to some extent.

\section{ACKNOWLEDGMENTS AND DISCLOSURES}

This study was funded by Academy of Finland (Grant number 257386). Finnish Cultural Foundation is also acknowledged for financial support. KMK and TM acknowledges the funding from the Academy of Finland and Sigrid Juselius Foundation. We thank Dr. Aaro Jalkanen for advice in designing microdialysis experiment, Prof. Seppo Auriola for consultation in LC-MS/MS analysis and Lecturer VeliPekka Ranta for advice regarding pharmacokinetics. Mrs. Jaana Leskinen, Mrs. Leena Pietilä and Mrs. Lea Pirskanen are acknowledged for technical assistance. The authors declare that they have no conflict of interest. All applicable international, national and institutional guidelines for the care and use of animals were followed. All procedures performed in studies involving animals were in accordance with the ethical standards of the University of Eastern Finland or practice at which the studies were conducted. This article does not contain any studies with human participants performed by any of the authors.

\section{REFERENCES}

1. Ballard C, Gauthier S, Corbett A, Brayne C, Aarsland D, Jones E. Alzheimer's disease. Lancet. 201 1;377(9770):1019-31.

2. Erickson MA, Banks WA. Blood-brain barrier dysfunction as a cause and consequence of Alzheimer's disease. J Cereb Blood Flow Metab. 2013;33(10):1500-13.

3. Stieger B, Gao B. Drug transporters in the central nervous system. Clin Pharmacokinet. 2015;54(3):225-42.

4. Uchida Y, Ohtsuki S, Katsukura Y, Ikeda C, Suzuki T, Kamiie J, et al. Quantitative targeted absolute proteomics of human bloodbrain barrier transporters and receptors. J Neurochem. 2011;117(2):333-45.

5. Agarwal S, Uchida Y, Mittapalli RK, Sane R, Terasaki T, Elmquist WF. Quantitative proteomics of transporter expression in brain capillary endothelial cells isolated from P-glycoprotein (Pgp), breast cancer resistance protein (Bcrp), and P-gp/Bcrp knockout mice. Drug Metab Dispos. 2012;40(6):1 164-9.

6. Geier EG, Chen EC, Webb A, Papp AC, Yee SW, Sadee W, et al. Profiling solute carrier transporters in the human blood-brain barrier. Clin Pharmacol Ther. 2013;94(6):636-9.

7. Nies AT, Jedlitschky G, Konig J, Herold-Mende C, Steiner HH, Schmitt HP, et al. Expression and immunolocalization of the multidrug resistance proteins, MRP1-MRP6 (ABCC1-ABCC6), in human brain. Neuroscience. 2004;129(2):349-60.

8. Hartz AM, Miller DS, Bauer B. Restoring blood-brain barrier Pglycoprotein reduces brain amyloid-beta in a mouse model of Alzheimer's disease. Mol Pharmacol. 2010;77(5):715-23.

9. Vogelgesang S, Cascorbi I, Schroeder E, Pahnke J, Kroemer HK, Siegmund W, et al. Deposition of Alzheimer's beta-amyloid is inversely correlated with P-glycoprotein expression in the brains of elderly non-demented humans. Pharmacogenetics. 2002;12(7):535-41. 
10. Wijesuriya HC, Bullock JY, Faull RL, Hladky SB, Barrand MA. $\mathrm{ABC}$ efflux transporters in brain vasculature of Alzheimer's subjects. Brain Res. 2010;1358:228-38.

11. Jeynes B, Provias J. An investigation into the role of P-glycoprotein in Alzheimer's disease lesion pathogenesis. Neurosci Lett. 2011;487(3):389-93.

12. Carrano A, Snkhchyan H, Kooij G, van der Pol S, van Horssen J, Veerhuis R, et al. ATP-binding cassette transporters P-glycoprotein and breast cancer related protein are reduced in capillary cerebral amyloid angiopathy. Neurobiol Aging. 2014;35(3):565-75.

13. Kannan P, Schain M, Kretzschmar WW, Weidner L, Mitsios N, Gulyas B, et al. An automated method measures variability in Pglycoprotein and ABCG2 densities across brain regions and brain matter. J Cereb Blood Flow Metab. 2016;01:27 1678X16660984.

14. van Assema DM, Lubberink M, Bauer M, van der Flier WM, Schuit $\mathrm{RC}$, Windhorst AD, et al. Blood-brain barrier P-glycoprotein function in Alzheimer's disease. Brain. 2012;135(Pt 1):181-9.

15. Xiong H, Callaghan D, Jones A, Bai J, Rasquinha I, Smith C, et al. ABCG2 is upregulated in Alzheimer's brain with cerebral amyloid angiopathy and may act as a gatekeeper at the blood-brain barrier for Abeta(1-40) peptides. J Neurosci. 2009;29(17):5463-75.

16. Mehta DC, Short JL, Nicolazzo JA. Altered brain uptake of therapeutics in a triple transgenic mouse model of Alzheimer's disease. Pharm Res. 2013;30(11):2868-79.

17. Do TM, Dodacki A, Alata W, Calon F, Nicolic S, Scherrmann JM, et al. Age-dependent regulation of the blood-brain barrier influx/efflux equilibrium of amyloid-beta peptide in a mouse model of Alzheimer's disease (3xTg-AD). J Alzheimers Dis. 2016;49(2):287-300.

18. Jankowsky JL, Fadale DJ, Anderson J, Xu GM, Gonzales V, Jenkins NA, et al. Mutant presenilins specifically elevate the levels of the 42 residue beta-amyloid peptide in vivo: evidence for augmentation of a 42-specific gamma secretase. Hum Mol Genet. 2004;13(2):159-70.

19. Jankowsky JL, Slunt HH, Ratovitski T, Jenkins NA, Copeland NG, Borchelt DR. Co-expression of multiple transgenes in mouse CNS: a comparison of strategies. Biomol Eng. 2001;17(6):157-65.

20. Hsiao K, Chapman P, Nilsen S, Eckman C, Harigaya Y, Younkin $\mathrm{S}$, et al. Correlative memory deficits, Abeta elevation, and amyloid plaques in transgenic mice. Science. 1996;274(5284):99-102.

21. Goisne C, Dehouck L, Faveeuw C, Delplace Y, Miller F, Landry C, et al. Mouse syngenic in vitro blood-brain barrier model: a new tool to examine inflammatory events in cerebral endothelium. Lab Investig. 2005;85(6):734-46.

22. Muller PY, Janovjak H, Miserez AR, Dobbie Z. Processing of gene expression data generated by quantitative real-time RT-PGR. BioTechniques. 2002;32(6):1372. -4, 1376, 1378-9

23. Sane R, Wu SP, Zhang R, Gallo JM. The effect of ABCG2 and ABCC4 on the pharmacokinetics of methotrexate in the brain. Drug Metab Dispos. 2014;42(4):537-40.

24. Pahnke J, Langer O, Krohn M. Alzheimer's and ABC transportersnew opportunities for diagnostics and treatment. Neurobiol Dis. 2014;72(Pt A):54-60.

25. Middeldorp J, Hol EM. GFAP in health and disease. Prog Neurobiol. 201 1;93(3):421-43.

26. Loryan I, Melander E, Svensson M, Payan M, Konig F, Jansson B, et al. In-depth neuropharmacokinetic analysis of antipsychotics based on a novel approach to estimate unbound target-site concentration in CNS regions: link to spatial receptor occupancy. Mol Psychiatry. 2016;21(11):1527-36.

27. Kuntner C, Bankstahl JP, Bankstahl M, Stanek J, Wanek T, Stundner G, et al. Dose-response assessment of tariquidar and elacridar and regional quantification of P-glycoprotein inhibition at the rat blood-brain barrier using $(\mathrm{R})-[(11) \mathrm{C}]$ verapamil PET. Eur J Nucl Med Mol Imaging. 2010;37(5):942-53.

28. Zhao R, Pollack GM. Regional differences in capillary density, perfusion rate, and P-glycoprotein activity: a quantitative analysis of regional drug exposure in the brain. Biochem Pharmacol. 2009;78(8):1052-9.

29. Brown WR, Thore CR. Review: cerebral microvascular pathology in ageing and neurodegeneration. Neuropathol Appl Neurobiol. 2011;37(1):56-74.

30. van de Steeg E, van der Kruijssen CM, Wagenaar E, BurggraaffJE, Mesman E, Kenworthy KE, et al. Methotrexate pharmacokinetics in transgenic mice with liver-specific expression of human organic anion-transporting polypeptide 1B1 (SLCO1B1). Drug Metab Dispos. 2009;37(2):277-81.

31. Badagnani I, Castro RA, Taylor TR, Brett CM, Huang CG, Stryke $\mathrm{D}$, et al. Interaction of methotrexate with organic-anion transporting polypeptide $1 \mathrm{~A} 2$ and its genetic variants. J Pharmacol Exp Ther. 2006;318(2):521-9.

32. Zhu Y, Meng Q Wang C, Liu Q Huo X, Zhang A, et al. Methotrexate-bestatin interaction: involvement of P-glycoprotein and organic anion transporters in rats. Int J Pharm. 2014;465(12):368-77.

33. Kanamitsu K, Kusuhara H, Schuetz JD, Takeuchi K, Sugiyama Y. Investigation of the importance of multidrug resistance-associated protein 4 (Mrp4/Abcc4) in the active efflux of anionic drugs across the blood-brain barrier. J Pharm Sci. 2017;106(9):2566-75.

34. Takeda M, Khamdang S, Narikawa S, Kimura H, Hosoyamada $\mathrm{M}$, Cha SH, et al. Characterization of methotrexate transport and its drug interactions with human organic anion transporters. J Pharmacol Exp Ther. 2002;302(2):666-71.

35. Hartz AM, Bauer B, Soldner EL, Wolf A, Boy S, Backhaus R, et al. Amyloid-beta contributes to blood-brain barrier leakage in transgenic human amyloid precursor protein mice and in humans with cerebral amyloid angiopathy. Stroke. 2012;43(2):514-23.

36. Bell RD, Winkler EA, Singh I, Sagare AP, Deane R, Wu Z, et al. Apolipoprotein E controls cerebrovascular integrity via cyclophilin A. Nature. 2012;485(7399):512-6.

37. de Lange EC, de Vries JD, Zurcher C, Danhof M, de Boer AG, Breimer DD. The use of intracerebral microdialysis for the determination of pharmacokinetic profiles of anticancer drugs in tumorbearing rat brain. Pharm Res. 1995;12(12):1924-31.

38. Bien-Ly N, Boswell CA, Jeet S, Beach TG, Hoyte K, Luk W, et al. Lack of widespread BBB disruption in Alzheimer's disease models: Focus on therapeutic antibodies. Neuron. 2015;88(2):289-97.

39. Cheng Z, Zhang J, Liu H, Li Y, Zhao Y, Yang E. Central nervous system penetration for small molecule therapeutic agents does not increase in multiple sclerosis- and Alzheimer's disease-related animal models despite reported blood-brain barrier disruption. Drug Metab Dispos. 2010;38(8):1355-61.

40. Kalvass JC, PolliJW, Bourdet DL, Feng B, Huang SM, Liu X, et al. Why clinical modulation of efflux transport at the human bloodbrain barrier is unlikely: the ITC evidence-based position. Clin Pharmacol Ther. 2013;94(1):80-94.

41. Kelly SD, Harrell CS, Neigh GN. Chronic stress modulates regional cerebral glucose transporter expression in an age-specific and sexually-dimorphic manner. Physiol Behav. 2014;126:39-49.

42. Flores K, Manautou JE, Renfro JL. Gender-specific expression of ATP-binding cassette $(\mathrm{Abc})$ transporters and cytoprotective genes in mouse choroid plexus. Toxicology. 2017;386:84-92. 